\title{
The current state of dyslipidemia in Korean children and adolescents and its management in clinical practice
}

\author{
Jung Sub Lim, MD, PhD \\ Department of Pediatrics, \\ Korea Cancer Center Hospital, \\ Seoul, Korea
}

Received: 13 February, 2013 Accepted: 18 February, 2013

Address for correspondence: Jung Sub Lim, MD, PhD Department of Pediatrics, Korea Cancer Center Hospital, 75 Nowonro, Nowon-gu, Seoul 139-706, Korea Tel: +82-2-970-1224

Fax: $+82-2-970-2427$

E-mail: limjs@kcch.re.kr
Cardiovascular disease (CVD) is a leading cause of death worldwide including Korea. The risk factors of CVD are known as positive family history of early CVD, obesity, hypertension, diabetes, and dyslipidemia. Among those, dyslipidemia is one of modifiable risk factors. Dyslipidemia starts in childhood and progress to adulthood. Furthermore, dyslipidemia cause atherosclerosis and is closely related to other CVD risks. On the rationale that early identification and control of pediatric dyslipidemia will reduce the risk and severity of CVD in adulthood, the National Heart, Lung, and Blood Institute guidelines expanded to universal screening for lipid levels. However, there was no guideline for lipid screening and management in Korean children and adolescents yet. This review deals with the rationale of early identification and control of pediatric dyslipidemia along with the current Korean status of pediatric dyslipidemia. This review also deals with how to screen, diagnosis, and treatment of pediatric dyslipidemia.

Keywords: Dyslipidemia, Children, Adolescents, Screening, Management

\section{Introduction}

Cardiovascular disease (CVD) is a leading cause of death worldwide in adults including Korea $^{1,2)}$. The prevalence of CVD in Korea was much lower than that in western countries. However, the CVD mortality rate increased and comparable to that in the USA recently ${ }^{2)}$. Now, the risk of CVD in Koreans, predicted using the Framingham model, was similar to that in the United States (US) population ${ }^{3)}$.

Dyslipidemia, abnormal amount of lipids in the blood such as hypercholesterolemia, begins in childhood and adolescence, and contributes to early atherosclerosis and to premature CVD even in young adult ${ }^{4-8)}$. Furthermore, dyslipidemia has been found to be closely related to other cardiovascular risk factors, such as hypertension, obesity, and smoking status, not only in adults but also in children and adolescents ${ }^{9,10)}$. Thus, the US expended the lipid screening in children and adolescents based on the rationale that early identification and control of pediatric dyslipidemia will reduce the risk and severity of CVD in adulthood. The National Heart, Lung, and Blood Institute (NHLBI) 2011 guidelines expanded to universal screening for lipid levels in children at 9 to 11 years of age and again at 17 to 21 years of age ${ }^{4)}$. However, there was no guideline for lipid screening and management in Korean children and adolescents yet.

The objectives of this review were as follows: (1) to explain the rationale that early identification and control of pediatric dyslipidemia might reduce the risk and severity of CVD in adulthood; (2) to show the prevalence of dyslipidemia in Korean children and adolescents; (3) to suggest pediatrician how to screening and management of dyslipidemia in clinical practice based on the American Academy of Pediatrics (AAP), American Heart Association (AHA), National Cholesterol Education Program (NCEP), and NHLBI guidelines ${ }^{4-8)}$. 


\section{Rationale of control of pediatric dyslipidemia}

Pediatric dyslipidemia is associated with atherosclerosis in adults. The evidence came from autopsy studies. In both the Pathobiological Determinants of Atherosclerosis in Youth (PDAY) study and the Bogalusa Heart Study, autopsy findings including children and young adults demonstrated an increase in atherosclerotic lesions in the coronary artery with increasing total cholesterol (TC), low-density lipoprotein cholesterol (LDL-C), and decreasing high-density lipoprotein cholesterol $(\mathrm{HDL}-\mathrm{C})^{10,11)}$. Atherosclerosis is responsible for CVD, such as myocardial infarction and stroke, by obstructing the arterial lumen or thrombotic emboli. In the PDAY study, atherosclerotic plaque was associated with the elevation of $\mathrm{TC}^{10)}$. In the Bogalusa Heart Study, the extent of atherosclerotic lesions increased with age and the prevalence was almost $70 \%$ in young adulthood ${ }^{11)}$. In addition, indirect markers of atherosclerosis, such as endothelial dysfunction assessed by flow-mediated dilation in the brachial artery and increased carotid intimamedia thickness, are associated with pediatric dyslipidemia ${ }^{12,133}$. Furthermore, pediatric dyslipidemia track to adulthood ${ }^{4,14)}$. Approximately half of the children with dyslipidemia will continue to have dyslipidemia in adulthood.

\section{Current state of serum lipid concentrations of Korean children and adolescents}

The serum lipid concentrations of Korean children and adolescents are similar to those of white counterpart. In US, normal pediatric values for serum lipids are derived from populationbased data from the Lipid Research Clinical Prevalence Study, and from the United States National Health and Nutrition Examination Surveys (NHANES) ${ }^{15,16)}$. In Korea, normal pediatric values for serum lipids concentration such as TC, LDL-C, TG, HDL-C are derived also from the Korea National Health and Nutrition Examination Surveys (KNHANES-IV) ${ }^{17)}$. The Korean references from KNHANES-IV are comparable with those of US as the measurement of each serum lipid followed the C37-A guideline of the Clinical and Laboratory Standards Institute and compared with for Disease Control and Prevention's Lipid Reference Laboratory.

The mean and 50th percentiles of TC and LDL-C concentrations were similar between Koreans and white individuals from the US, but the 95th percentile values for Koreans were less than those obtained for white individuals from the US. The 50th, 75th, 90th, and 95th percentiles for LDL-C were 87, 104, 119 , and $127 \mathrm{mg} / \mathrm{dL}$, respectively, for Korean boys and 90, 106, 121 , and $132 \mathrm{mg} / \mathrm{dL}$, respectively, for girls. The corresponding numbers for white boys were $85,103,124$, and $136 \mathrm{mg} / \mathrm{dL}$, and those for girls were $88,104,122$, and $133 \mathrm{mg} / \mathrm{dL}$, respectively ${ }^{18)}$. The TG profile showed a similar pattern. The 50th and 95th percentiles for TG concentrations were 73 and $189 \mathrm{mg} / \mathrm{dL}$ for Korean boys and 80 and $181 \mathrm{mg} / \mathrm{dL}$ for girls. The 50th and 95th percentiles for white boys were 76 and $205 \mathrm{mg} / \mathrm{dL}$, respectively and for white girls were 80 and $218 \mathrm{mg} / \mathrm{dL}^{16)}$. However, Korean showed low level of HDL-C. The 5th and 50th percentiles for HDL-C concentrations were 35 and $48 \mathrm{mg} / \mathrm{dL}$ for Korean boys and 37 and $50 \mathrm{mg} / \mathrm{dL}$ for girls. In comparison, 37 and $53 \mathrm{mg} / \mathrm{dL}$ for white boys and 36 and $54 \mathrm{mg} / \mathrm{dL}$ for white girls ${ }^{16)}$.

\section{Prevalence of pediatric dyslipidemia in Korean children and adolescents}

As there was cutoff points of pediatric dyslipidemia in Korean children and adolescents, Yang et al. ${ }^{17)}$ adopted US guidelines. According to the cutoff points of the NCEP and AHA guidelines, $19.7 \%$ of Korean children and adolescents, aged 10 to 18 years, had at least one abnormal lipid concentration. The estimated prevalence of hypercholesterolemia was $6.5 \%$. The prevalence of high LDL-C was $4.7 \%$. The prevalence of high TG $(>150 \mathrm{mg} / \mathrm{dL})$ and low HDL-C $(<35 \mathrm{mg} / \mathrm{dL})$ was $10.1 \%$ and $7.1 \%$, respectively. If defined low HDL-C as $<40 \mathrm{mg} / \mathrm{dL}$, the prevalence of low HDL-C was $14.5 \%$. The prevalence of hypercholesterolemia and high LDL-C was greater in girls than in boys $(7.4 \%$ vs. $5.8 \%$ and $5.5 \%$ vs. $4.1 \%)$ but lower low HDL-C prevalence (5.5\% vs. $8.5 \%)$. However, boys showed increased prevalence of dyslipidemia with aging while girls did not. The prevalence of dyslipidemia was higher with greater body mass index (BMI). The prevalence dyslipidemia increased from 20.7\% to $39.6 \%$ to $56.1 \%$ for boys ( $24.5 \%$ to $36.6 \%$ to $53.1 \%$ for girls) who were normal weight, overweight, and obese, respectively ${ }^{19)}$. In USA data from NHANES (1996 to 2006) also showed, the prevalence dyslipidemia increased according to weight status $(14.2 \%, 22.3 \% \text {, and } 42.9 \% \text { respectively })^{20)}$. The prevalence of dyslipidemia in Korean including children and adolescents had been increased. In adults (aged $\geq 20$ years), the prevalence of dyslipidemia increased from $32.4 \%$ in 1998 to $44.1 \%$ in 2005 . Compared with the KNHANES in 1998, the prevalence of dyslipidemia was $61 \%$ higher in $2005^{33}$. In Korean children and adolescents, the mean LDL-C concentration of increased from $89.3 \pm 0.8$ to $96.5 \pm 1.2 \mathrm{mg} / \mathrm{dL}$ during 1998 to 2001 . Furthermore, the prevalence of high TG $(>110 \mathrm{mg} / \mathrm{dL})$ and low HDL-C $\left(<40 \mathrm{mg} / \mathrm{dL}\right.$ ) increased by $6.2 \%$ and $10.5 \%{ }^{21}$. The other problem is only $9.5 \%$ of people with dyslipidemia were aware of the disease, $5.2 \%$ used lipid-lowering medication even in adults. In comparison, the prevalence of pediatric dyslipidemia in the US children and adolescents was decreased. The data from the NHANES showed improving mean lipid levels and rates of dyslipidemia from 1988-1994 to 2007-2010 in US ${ }^{22}$. Mean TC declined from 165 to $160 \mathrm{mg} / \mathrm{dL}$ and the prevalence of elevated TC $(\geq 200 \mathrm{mg} / \mathrm{dL}$ ) decreased from $11.3 \%$ to $8.1 \%$. Mean LDL-C levels in adolescents decreased from 95 to $90 \mathrm{mg} / \mathrm{dL}$ and the prevalence of elevated LDL-C $(\geq 130 \mathrm{mg} / \mathrm{dL})$ decreased from $11.9 \%$ to $7.4 \%$. Mean TG also decreased from 82 to $73 \mathrm{mg} / \mathrm{dL}$ and the prevalence of elevated TG $(\geq 130 \mathrm{mg} / \mathrm{dL})$ decreased from $17.3 \%$ to $12.4 \%$. 


\section{Definition of pediatric dyslipidemia}

It is well known that the lipid concentration differ according to age, sexual, and ethnicity. Thus, Korean specific guidelines, including pediatric dyslipidemia cutoff points, should be made. Until then, I suggest Korean pediatrician to apply US guidelines with some modification in screening and management of Korean pediatric dyslipidemia in clinical practice. In US, NHLBI expert panel revised cutoff points in 2011, initially developed by the NCEP and the AAP based on population distributions ${ }^{4}$. These cutoff points are based on the US normative data and delineate lipid values as acceptable, borderline, and abnormal (Table 1). The cutoff points of TC and LDL-C of the NHLBI, the NCEP and the AAP are same. However, discrepancies exist on the cutoff points of TG and HDL-C according to organizations. The AHA has recommended that TG of $>150$ $\mathrm{mg} / \mathrm{dL}$ and HDL-C of $<35 \mathrm{mg} / \mathrm{dL}$ be considered abnormal for children and adolescents ${ }^{8}$. The International Diabetes Federal recommended that TG of $\geq 150 \mathrm{mg} / \mathrm{dL}$ and HDL-C of $<40$ $\mathrm{mg} / \mathrm{dL}$ ( $<50 \mathrm{mg} / \mathrm{dL}$ in case female over 16 years) be considered abnormal for children and adolescents ${ }^{23)}$.

Considering KNHANES-IV finding, adopt the cutoff points of TC ( > $200 \mathrm{mg} / \mathrm{dL})$ and LDL-C (>130 mg/dL), which correspond 95th percentile of Korean children and adolescents, as abnormal is no problem. In TG, I suggest the cutoff points of $\geq 150 \mathrm{mg} / \mathrm{dL}$, which correspond 90th percentile of Korean children and adolescents, as abnormal. However, increasing evidence suggests that TG concentration relates CVD risk especially in Asian including Korean ${ }^{24,25)}$. In HDL-C, the cutoff points of $<40 \mathrm{mg} / \mathrm{dL}$, which correspond 10th percentile of Korean children and adolescents, as abnormal without gender difference. Further evidences are needed to set the cutoff points of TG and HDL-C in Korean children and adolescents.

Table 1. Cutoff point for lipid concentrations in children and adolescents

\begin{tabular}{lcccc}
\hline Category & $\begin{array}{c}\text { Acceptable } \\
(\mathrm{mg} / \mathrm{dL})\end{array}$ & $\begin{array}{c}\text { Borderline } \\
(\mathrm{mg} / \mathrm{dL})\end{array}$ & $\begin{array}{c}\text { Abnormal } \\
(\mathrm{mg} / \mathrm{dL})\end{array}$ & Percentile $^{\text {a) }}$ \\
\hline TC & $<170$ & $170-199$ & $\geq 200$ & $\approx 94$ th \\
LDL-C & $<110$ & $110-129$ & $\geq 130$ & $\approx 95$ th \\
Non-HDL-C & $<120$ & $120-144$ & $\geq 145$ & \\
Triglycerides & & & & \\
0-9yr & $<75$ & $75-99$ & $>100$ & \\
10-19yr & $<90$ & $90-129$ & $\geq 130$ & $\approx 83$ th \\
HDL-C & $>45$ & $40-45$ & $<40$ & $\approx 11$ th \\
\hline
\end{tabular}

TC, total cholesterol; LDL-C, low density lipoprotein cholesterol; HDL-C, high density lipoprotein cholesterol.

Adapted from National Cholesterol Education Program guidelines and National Heart, Lung, and Blood Institute 2011 guidelines for children and adolescents ${ }^{7}$.

a) Percentile value of each abnormal serum lipid concentration based on Korea National Health and Nutrition Examination Surveys data.

\section{Lipid screening}

Screening for lipids in children is based on the rationale that early identification and control of pediatric dyslipidemia will reduce the risk and severity of CVD in adulthood ${ }^{4)}$. The AAP, NCEP and AHA Expert Panel have recommended 'selective screening' of children and adolescents with high risk of CVD ${ }^{8}$. The 2011 NHLBI guidelines added 'universal screening' based on the following reasons ${ }^{4)}$. Lipid disorders are clinically silent in the vast majority of cases. Abnormal LDL-C levels in children with positive family history were similar to those found in children without concerning family history ${ }^{26)}$. Many children with familiar hypercholesterolemia (FH) may also be missed by selective screening, especially if their parents are young, free of CVD, and unaware of their own lipid levels. Selective screening based on family history of CVD or hypercholesterolemia will fail to detect substantial numbers (from 17\% to 90\%) of children who have elevated lipid levels ${ }^{27)}$. Thus, universal screening might be performed to detect those with undiagnosed heterozygous $\mathrm{FH}$, who will require more intensive treatment, including the possibility of pharmacological therapy ${ }^{4,28)}$.

In selective screening, children over 2 years of age, with a 1st or 2nd degree relative (parents, grand-parents, uncles, and ants) with documented CVD before age 55 in men and 65 in women, should undergo a fasting lipid profile. Fasting lipid profiles such as TC, TG, and HDL-C should be measured by wellstandardized immunochemical methods. LDL-C is calculated from the Friedewald equation: $\mathrm{LDL}-\mathrm{C}=\mathrm{TC}-(\mathrm{HDL}-\mathrm{C}+\mathrm{TG} / 5)$. If TG is more than $400 \mathrm{mg} / \mathrm{dL}$, this formula cannot be used. The use of a direct LDL-C measurement is not recommended ${ }^{29)}$. Non-HDL-C is calculated as; Non-HDL-C=TC-HDL-C. Non-HDL cholesterol includes all cholesterol present in lipoprotein particles (LDL-C, lipoprotein(a), intermediatedensity lipoprotein, and very-low-density lipoprotein) that are considered atherogenic. Non-HDL is a better independent predictor of CVD than LDL-C and is good predictor of future dyslipidemia in adulthood as LDL-C ${ }^{30)}$. CVD is defined as any of angina pectoris, peripheral or cerebral vascular disease, myocardial infarction, documented coronary artery disease or sudden death. A positive family history of premature coronary artery disease doubles the risk of CVD in children including Korean ${ }^{10,31)}$. Children with known disease associated with increased risk for CVD also should be screened for dyslipidemia. The following conditions associated with risk of CVD: FH, parents with TC $>240 \mathrm{mg} / \mathrm{dL}$, excessive exposure to smoking, type 1 and 2 diabetes mellitus, nephrotic syndrome, chronic renal disease, hypertension, history of Kawasaki disease or childhood cancer, some forms of congenital heart disease, juvenile rheumatoid arthritis, inflammatory bowel disease, overweight (age $>8$ years), and obesity ${ }^{4-8,32}$. In overweight Korean children and adolescents (4th grade elementary, 1st grade middle, and 1st grade high school student), the 'revised a school health measure 2006 ' reinforce routine TC screening. If $\mathrm{TC} \geq 200 \mathrm{mg} / \mathrm{dL}$ or repeated mean is $\geq 170 \mathrm{mg} / \mathrm{dL}$, fasting lipid screening is recommended by law ${ }^{33)}$. 
In universal screening, first screening performed between 9 and 11 years of age. Second screening performed between 17 and 21 years of age. The serum lipid concentration especially LDL-C decreases during puberty and growth ${ }^{4)}$. For universal screening, nonfasting TC and HDL-C can be measured accurately and more practical screening test for pediatric patients than a fasting profile. In an analysis from the Bogalusa study, non-HDL-C was at least as good a predictor as other lipid tests for increased carotid intima-media thickness and were predictive of adult dyslipidemia independent of baseline BMI and BMI changes ${ }^{34)}$.

If the screening test is abnormal, fasting lipid profiles should be measured at least twice at intervals between two weeks and three months with counseling lifestyle modification ${ }^{4)}$. The average values are used to determine the need for therapeutic interventions. If the dyslipidemia persists, secondary causes of dyslipidemia must be ruled out ${ }^{32)}$.

\section{How to manage pediatric dyslipidemia}

Diagnostic and management algorithm for pediatric dyslipidemia is depicted in Fig. 1. Current guidelines strongly advocate dietary treatment and lifestyle changes as the primary therapeutic method. If these fail to correct dyslipidemia sufficiently, then pharmacologic treatment should be considered.

The primary target of most guidelines is LDL-C. The NHLBI guidelines added TG as additional target. In NHLBI guidelines, Cardiovascular Health Integrated Lifestyle Diet (CHILD), this is expended diet with modification of step diet. If LDL-C concentration is borderline ( 110 to $129 \mathrm{mg} / \mathrm{dL}$ ), a step I diet and life style change are recommended and get a repeat test at 1 year. If LDL-C concentration is abnormal $(\geq 130 \mathrm{mg} / \mathrm{dL})$, the step I diet and life style change are recommended and get a repeat test at 3 months. If persist, recommend a step II diet, additional fiber, and plant sterols, with or without lipid lowering medications. The initiation of lipid-lowering medication will depend on LDL levels, presence of other CVD risk factors, and family history of premature CVD. In case of hypertriglyceridemia ( $\geq 130 \mathrm{mg} /$ $\mathrm{dL})$, life style modification with or without omega-3 fatty acids are recommended. In case of very high triglyceride levels ( > $500 \mathrm{mg} / \mathrm{dL}$ ) with risk of acute pancreatitis, consider statins or fibrates $^{4,35)}$.

\section{Dietary treatment}

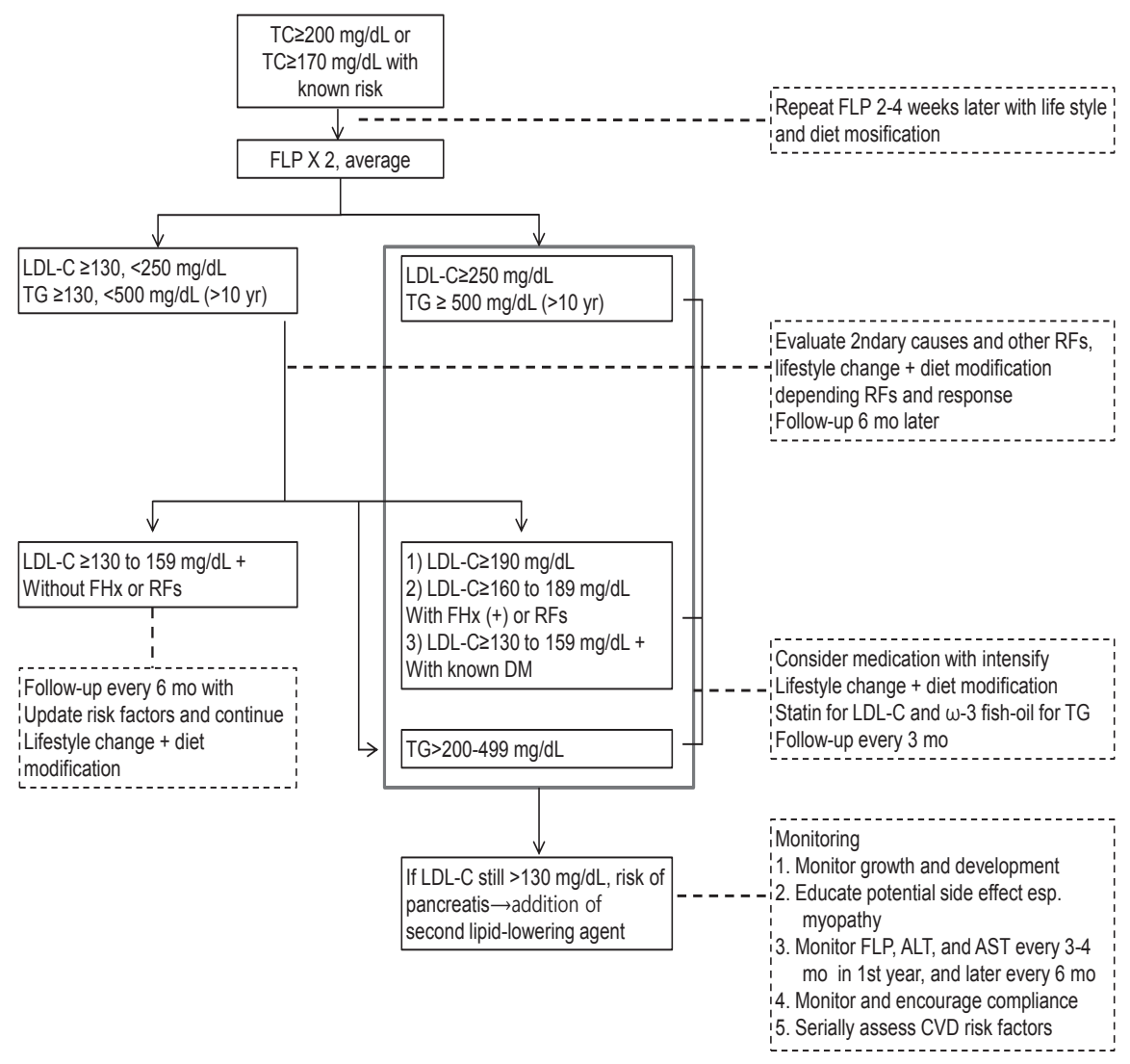

Fig. 1. Diagnostic and therapeutic algorithm for children and adolescents with elevated low-density lipoprotein cholesterol (LDL-C) and triglycerides (TG). TC, total cholesterol; FHx, family history; RFs, risk factors; FLP, fasting lipid profile; DM, diabetes mellitus; ALT, alanine aminotransferase; AST, aspartate aminotransferase; CVD, cardiovascular disease. 
The NCEP pediatric panel recommended diet treatment after 2 years of age ${ }^{7)}$. Recent data indicate that a diet may be instituted safely and effectively at 6 months of age under medical supervision ${ }^{4-6)}$. Children and adolescents with dyslipidemia are first treated with a diet reduced in total fat, saturated fat, and cholesterol ${ }^{4-8)}$. The AHA step I diet is usually started and the lipoprotein profile repeated in 6 to 8 weeks. If the dyslipidemia persists, then a more stringent step II diet is initiated $^{36)}$. The step I diet consist of a diet with $<10 \%$ calories from saturated fat, $30 \%$ calories from fat, and $<300 \mathrm{mg} /$ day from cholesterol. The CHILD-1, recommended recently by NHLBI, is more specific; Primary beverage is fat-free unflavored milk, limit/avoid sugar-sweetened beverages, encourage water, fat content (total fat $25 \%$ to $30 \%$ of daily $\mathrm{kcal} /$ EER [estimated energy requirements per day for age/gender], saturated fat $8 \%$ to $10 \%$ of daily kcal/EER, avoid trans fat as much as possible, recommend monounsaturated and polyunsaturated fat up to $20 \%$ of daily $\mathrm{kcal} / \mathrm{EER}$ ), and recommend $<300 \mathrm{mg} /$ day from cholesterol. In addition, recommend supportive actions such as teach portions based on EER, encourage moderate-to-vigorous physical activity, advocate dietary fiber ( $14 \mathrm{~g} / 1,000 \mathrm{kcal})$, limit naturally sweetened juice (no added sugar) to $120 \mathrm{~mL} /$ day, limit sodium intake, and encourage healthy eating habits ${ }^{4)}$. The step II diet is more stringent diet plan with $<10 \%$ calories from saturated fat and $<200 \mathrm{mg} /$ day from cholesterol. The CHILD-2 is more specific. The CHILD-2 is divided CHILD-2-LDL and CHILD-2-TG depends on the target of dyslipidemia. The main things are refer children and adolescents to a registered dietitian for family medical nutrition therapy, decrease sugar intake. The CHILD-2 recommended 25\% to 30\% of calories from fat, $<7 \%$ from saturated fat, $\approx 10 \%$ from monounsaturated fat, $<200$ $\mathrm{mg} /$ day of cholesterol, and avoid trans-fats. Recommended supportive actions are differ CHILD-2-LDL and CHILD-2-TG.

Dietary supplements might help to control dyslipidemia but are not encouraged as monotherapy. Plant sterols and stanols, the plant versions of cholesterol and known to help block the absorption of dietary cholesterol into the body, can be used in children with monitoring for effects on absorption of fatsoluble vitamins ${ }^{37}$. The Food and Drug Administration (FDA) has approved health claims on plant sterols as a supplement and food additive. Plant sterols are effective in lowering TC and LDL-C by $10-15 \%$ in adults ${ }^{6,37)}$. The FDA has declared that the consumption of soluble fiber may reduce the risk of heart disease. Fiber binds with cholesterol in bile acids and removes it from the enterohepatic circulation. An appropriate dose is calculated as the child's age plus $5 \mathrm{~g} /$ day, up to a dose of $20 \mathrm{~g} /$ day at 15 years of age ${ }^{36)}$. Soy protein lowers VLDL-C and TG but not LDL-C and increases HDL-C ${ }^{38)}$ omega- 3 fatty acids (docosahexaenoic acid $1.2 \mathrm{~g} /$ day) did not lower LDL-C but significantly decreased the smallest LDL-C subclass to $48 \%{ }^{39)}$.

\section{Lifestyle changes}

Increasing dyslipidemia in Korean children and adolescents might be due to recent changes promoting a western lifestyle, especially westernized diet and decrease in physical activity ${ }^{40,41)}$. Thus, children and adolescents should be encouraged to indulge in 60 minutes or more of vigorous play or aerobic activity per day as recommended ${ }^{4)}$. Sedentary time including television, internet and videogames time should be reduced as possible. Cigarette exposure also should be actively discouraged.

\section{Pharmacologic treatment}

Pharmacological treatment is recommended in children $\geq 10$ years with poor response to diet and lifestyle therapy at least 6 to 12 months. The choice of pharmacological is depends on the lipid profile, age, gender, family history of the patient, and pediatricians' experience ${ }^{4,42)}$. Recent guidelines focus on lowering the LDL-C and TG in high-risk children and adolescents below cutoff levels ${ }^{4-8}$. Pharmacological treatment to lower LDL-C is initiated (1) if LDL-C is more than $190 \mathrm{mg} /$ $\mathrm{dL}$ or (2) more than $160 \mathrm{mg} / \mathrm{dL}$ and there is a family history of premature CVD or two or more risk factors for CVD such as

Table 2. Currently using medications for dyslipidemia

\begin{tabular}{|c|c|c|c|}
\hline Type of medication & Major effects & Adverse reactions & Medication \\
\hline $\begin{array}{l}\text { HMG-Co A reductase } \\
\text { Inhibitors (statins) }\end{array}$ & $\begin{array}{l}\text { Mainly } \downarrow \text { cholesterol and VLDL synthesis } \\
/ \uparrow \text { Hepatic LDL receptors, } \downarrow \text { LDL-C, } \\
\text { small } \downarrow T G \text {, modest } \uparrow \text { HDL-C }\end{array}$ & $\begin{array}{l}\uparrow \text { hepatic enzymes, } \uparrow \text { creatine kinase, } \\
\text { myopathy, rhabdomyolysis }\end{array}$ & $\begin{array}{l}\text { Atorvastatin } 10 \mathrm{mg} / \text { day, Simvastatin } 20 \\
\text { mg/day, pravastatin } 20 \mathrm{mg} / \text { day with and } \\
\text { gradual titration }\end{array}$ \\
\hline Bile acid sequestrants & $\begin{array}{l}\text { Mainly } \uparrow \text { Bile and excretion, } \uparrow \text { LDL-C, } \\
\text { small } \uparrow \mathrm{HDL}-\mathrm{C} \text { but } \uparrow \mathrm{TG}\end{array}$ & $\begin{array}{l}\text { Gastrointestinal trouble: gas, bloating, } \\
\text { constipation, cramps }\end{array}$ & $\begin{array}{l}\text { Cholestyramine } 8 \text { g/day, colestipol 2-12 } \\
\text { g/day }\end{array}$ \\
\hline $\begin{array}{l}\text { Cholesterol } \\
\text { absorption inhibitors }\end{array}$ & $\begin{array}{l}\text { Mainly } \downarrow \text { Intestinal absorption } \\
\text { cholesterol, } \downarrow \text { LDL-C, small } \downarrow \text { TG, } \\
\text { small } \uparrow \text { HDL-C }\end{array}$ & $\begin{array}{l}\text { Myopathy, gastrointestinal trouble, } \\
\text { headache }\end{array}$ & Ezetimibe 10 mg/day \\
\hline Fibric acid derivatives & Mainly $\downarrow$ VLDL, mainly $\downarrow$ TG, $\uparrow \mathrm{HDL}-\mathrm{C}$ & Dyspepsia, constipation, myositis, anemia & Bezafibrate $10-20$ mg/ day \\
\hline Nicotinic acid & $\begin{array}{c}\text { Mainly } \downarrow \text { Hepatic VLDL synthesis, } \downarrow \text { TG, } \\
\downarrow \text { LDL-C, } \uparrow \text { HDL-C, } \downarrow \text { lipoprotein(a) }\end{array}$ & $\begin{array}{l}\text { Flushing, hepatic toxicity, } \uparrow \text { fasting blood } \\
\text { glucose, } \uparrow \text { uric acid, hyperacidity }\end{array}$ & $\begin{array}{l}\text { Niacin } 50 \mathrm{mg} / \text { day with and } \\
\text { gradual titration }\end{array}$ \\
\hline Fish oil & $\begin{array}{l}\text { Mainly } \downarrow \text { VLDL production, } \downarrow \mathrm{TG} \text {, } \\
\uparrow \mathrm{HDL}-\mathrm{C}, \uparrow \mathrm{LDL}-\mathrm{C} \text { but } \uparrow \text { particle size }\end{array}$ & Sometimes gastrointestinal trouble & w-3 fish oils (1 g per capsule) 1-4 g/day \\
\hline
\end{tabular}

HMG-Co A, hydroxymethylglutaryl coenzyme A; VLDL, very low-density lipoprotein; LDL-C, low density lipoprotein cholesterol; TG, triglycerides; HDL-C, high density lipoprotein cholesterol; TC; total cholesterol. 
hypertension, obesity, or smoking. In NHLBI guidelines, the risk factors are divided as high-level risk factors and moderate-level risk factors.

According to the AAP guidelines, at least $0.41 \%$ of Korean children and adolescents are eligible for pharmacological treatment ${ }^{17)}$. The statins and the bile acid-binding resins are the two main classes of medications currently used. Bile acidbinding resins were the only class of medications recommended by NCEP for pharmacological lipid-lowering therapy because of their long track record of safety. Most statins are approved as an adjunct to diet to lower LDL-C aged 10 to 18 years by FDA and recommended as 1st line of therapy by NHLBI. The commonly used medications are listed in Table 2. Cholesterol-absorption inhibitors, niacin, and fibrates are not approved currently by FDA and used.

\section{3-hydroxy-3-methyl-glutaryl coenzyme A (HMG-Co A) reductase inhibitors (statins)}

Statins inhibit the rate-limiting enzyme HMG-Co A reductase for endogenous synthesis of cholesterol. Statins are the drug of choice for high LDL-C in adults, and are becoming popular in children. Evidence regarding the safety and efficacy of statins in children and adolescents over a period of 24 months is available and its safety and efficacy is similar to adults ${ }^{43-45)}$. In general, they are effective in lowering cholesterol of $20 \%$ to $50 \%$ below baseline. Statins showed minimal side effects, without affecting growth, maturation. Atorvastatin and simvastatin are approved in boys $\geq 10$ years of age. In children with high LDL-C and strong risk factors, encourage the use of statins prior to age 10 . Starts low dose (atorvastatin $10 \mathrm{mg}$ and simvastatin $20 \mathrm{mg}$ /day) and gradual upward titration with monitoring LDL-C and side effects. Liver function tests and creatine kinase check-up are recommended every 3 to 4 months in children. Grapefruit juice, cyclosporine, and erythromycin have possible pharmacological interactions with statins.

\section{Bile acid-binding resins (cholestyramine and colestipol)}

Bile acid-binding resins are the first line therapy for children with dyslipidemia as it does no systemically absorbed ${ }^{46)}$. It work by preventing cholesterol reuptake in enterohepatic circulation and $10 \%$ to $20 \%$ below baseline cholesterol and it upregulates LDL receptors. However, cholestyramine and colestipol are unpalatable and associated with gastro intestinal side effects. Thus, compliance to this therapy is very poor.

\section{Cholesterol-absorption inhibitors (ezetimibe)}

Ezetimibe enters the enterohepatic circulation and reduces bile acid reuptake as well as absorption of cholesterol. Ezetimibe is approved in children above 10 years of age, in a dose of 10 $\mathrm{mg} /$ day, as an adjuvant to statin therapy. In adults, ezetimibe has been shown to reduce LDL-C by $20 \%{ }^{47)}$. Although, attractive pharmacological for use in the young age, studies are very few.

\section{Niacin and fibrates}

Because of severe adverse effects, these pharmacologicals are not recommended for routine use. These pharmacologicals are used in combination by lipid specialist with special occasion. Niacin is the most potent HDL-C enhancer and recommended only as adjunctive therapy in children ${ }^{4,42}$. In children, flushing occurred in $76 \%$ and elevation of hepatic transaminase occurred in 26\%. Fibrates (fenofibrate and bezafibrate) are used in children with very high triglyceride levels $(>500 \mathrm{mg} / \mathrm{dL})$ to prevent pancreatitis ${ }^{35)}$. However, elevation of liver enzymes, gastrointestinal symptoms, and predisposition to cholelithiasis can occur. In combination with statins predisposes children to rhabdomyolysis.

\section{Conclusions}

This review has tried to address the rationale of screening and management of dyslipidemia in children and adolescents. Dyslipidemia begins in childhood and adolescence, progress to adulthood, and cause to CVD in adulthood. The prevalence of dyslipidemia has increased and reached up to $44.1 \%$ in Korean adult. The current prevalence of dyslipidemia is $19.7 \%$ in Korean children and adolescents, the most common disorder. However, most Korean people including pediatricians are not aware of the importance of managing dyslipidemia. Pediatricians should aware that dyslipidemia is easily modifiable risk factor of CVD and early screening and management of pediatric dyslipidemia will reduce the future risk and severity of CVD in adulthood. As Korean studies on pediatric dyslipidemia are scarce, this review has cited many parts of US studies. Further studies are required especially the effectiveness and safety of pharmacological managements on Korean children and adolescents.

\section{Conflict of interest}

No potential conflict of interest relevant to this article was reported.

\section{References}

1. World Health Organization (WHO). The global burden of disease: 2004 update [Internet]. Geneva: WHO; c2013 [cited 2013 Jan 15]. Available from: http://www. who.int/healthinfo/global_burden_disease/GBD_ report_2004update_full.pdf.

2. Statistics Korea. Annual report on the cause of death statistics, 2010 [Internet]. Daejeon: Statistics Korea; [2013 Jan 9]. Available from: http://kostat.go.kr/portal/english/ 
news $/ 1 / 8 /$ index.board bmode $=$ read $\& b S e q=\& a S e q=25042$ 7 \&page $\mathrm{No}=1$ \&rowNum $=10$ \&navCount $=10 \&$ currPg $=\& \mathrm{sT}$ arget=title.

3. Lee MH, Kim HC, Ahn SV, Hur NW, Choi DP, Park CG, et al. Prevalence of dyslipidemia among Korean adults: Korea National Health and Nutrition Survey 1998-2005. Diabetes Metab J 2012;36:43-55.

4. Expert Panel on Integrated Guidelines for Cardiovascular Health and Risk Reduction in Children and Adolescents; National Heart, Lung, and Blood Institute. Expert panel on integrated guidelines for cardiovascular health and risk reduction in children and adolescents: summary report. Pediatrics 2011;128 Suppl 5:S213-56.

5. Daniels SR, Greer FR; Committee on Nutrition. Lipid screening and cardiovascular health in childhood. Pediatrics 2008;122:198-208.

6. Kwiterovich PO Jr. Recognition and management of dyslipidemia in children and adolescents. J Clin Endocrinol Metab 2008;93:4200-9.

7. National Cholesterol Education Program (NCEP): highlights of the report of the Expert Panel on Blood Cholesterol Levels in Children and Adolescents. Pediatrics 1992;89:495-501.

8. Kavey RE, Daniels SR, Lauer RM, Atkins DL, Hayman LL, Taubert K, et al. American Heart Association guidelines for primary prevention of atherosclerotic cardiovascular disease beginning in childhood. Circulation 2003; 107:1562-6.

9. McGill HC Jr, McMahan CA, Zieske AW, Malcom GT, Tracy RE, Strong JP. Effects of nonlipid risk factors on atherosclerosis in youth with a favorable lipoprotein profile. Circulation 2001;103:1546-50.

10. McGill HC Jr, McMahan CA, Zieske AW, Sloop GD, Walcott JV, Troxclair DA, et al. Associations of coronary heart disease risk factors with the intermediate lesion of atherosclerosis in youth. The Pathobiological Determinants of Atherosclerosis in Youth (PDAY) Research Group. Arterioscler Thromb Vasc Biol 2000;20:1998-2004.

11. Berenson GS, Srinivasan SR, Bao W, Newman WP 3rd, Tracy RE, Wattigney WA. Association between multiple cardiovascular risk factors and atherosclerosis in children and young adults. The Bogalusa Heart Study. N Engl J Med 1998;338:1650-6.

12. Li S, Chen W, Srinivasan SR, Bond MG, Tang R, Urbina EM, et al. Childhood cardiovascular risk factors and carotid vascular changes in adulthood: the Bogalusa Heart Study. JAMA 2003;290:2271-6.

13. Juonala M, Viikari JS, Ronnemaa T, Marniemi J, Jula A, Loo $\mathrm{BM}$, et al. Associations of dyslipidemias from childhood to adulthood with carotid intima-media thickness, elasticity, and brachial flow-mediated dilatation in adulthood: the Cardiovascular Risk in Young Finns Study. Arterioscler Thromb Vasc Biol 2008;28:1012-7.

14. Bao W, Srinivasan SR, Wattigney WA, Bao W, Berenson GS. Usefulness of childhood low-density lipoprotein cholesterol level in predicting adult dyslipidemia and other cardiovascular risks. The Bogalusa Heart Study. Arch Intern Med 1996;156:1315-20.

15. Christensen B, Glueck C, Kwiterovich P, Degroot I, Chase G, Heiss G, et al. Plasma cholesterol and triglyceride distributions in 13,665 children and adolescents: the Prevalence Study of the Lipid Research Clinics Program. Pediatr Res 1980;14:194-202.

16. Hickman TB, Briefel RR, Carroll MD, Rifkind BM, Cleeman JI, Maurer KR, et al. Distributions and trends of serum lipid levels among United States children and adolescents ages 4-19 years: data from the Third National Health and Nutrition Examination Survey. Prev Med 1998;27:879-90.

17. Yang S, Hwang JS, Park HK, Lee HS, Kim HS, Kim EY, et al. Serum lipid concentrations, prevalence of dyslipidemia, and percentage eligible for pharmacological treatment of Korean children and adolescents; data from the Korea National Health and Nutrition Examination Survey IV (2007-2009). PLoS One 2012; 7:e49253.

18. Ford ES, Li C, Zhao G, Mokdad AH. Concentrations of lowdensity lipoprotein cholesterol and total cholesterol among children and adolescents in the United States. Circulation 2009;119:1108-15.

19. Kim SH, Ahn BC, Joung H, Park MJ. Lipid profiles and prevalence of dyslipidemia in Korean adolescents. Endocrinol Metab 2012;27:208-16.

20. Centers for Disease Control and Prevention (CDC). Prevalence of abnormal lipid levels among youths: United States, 1999-2006. MMWR Morb Mortal Wkly Rep 2010;59:29-33

21. Lim S, Jang HC, Park KS, Cho SI, Lee MG, Joung H, et al. Changes in metabolic syndrome in American and Korean youth, 1997-2008. Pediatrics 2013;131:e214-22.

22. Kit BK, Carroll MD, Lacher DA, Sorlie PD, DeJesus JM, Ogden C. Trends in serum lipids among US youths aged 6 to 19 years, 1988-2010. JAMA 2012;308:591-600.

23. Zimmet P, Alberti KG, Kaufman F, Tajima N, Silink M, Arslanian S, et al. The metabolic syndrome in children and adolescents: an IDF consensus report. Pediatr Diabetes 2007;8:299-306

24. McBride PE. Triglycerides and risk for coronary heart disease. JAMA 2007;298:336-8.

25. Patel A, Barzi F, Jamrozik K, Lam TH, Ueshima H Whitlock G, et al. Serum triglycerides as a risk factor for cardiovascular diseases in the Asia-Pacific region. Circulation 2004;110:2678-86.

26. Ritchie SK, Murphy EC, Ice C, Cottrell LA, Minor V, Elliott E, et al. Universal versus targeted blood cholesterol screening among youth: The CARDIAC project. Pediatrics 2010;126:260-5

27. Haney EM, Huffman LH, Bougatsos C, Freeman M, Fu R, Steiner RD, et al. Screening for lipid disorders in children and adolescents [Internet]. Rockville: Agency for Healthcare Research and Quality; 2007 [cited 2013 Jan 17]. Available from: http://www.ncbi.nlm.nih.gov/books/ 
NBK33480/.

28. US Preventive Services Task Force. Screening for lipid disorders in children: US Preventive Services Task Force recommendation statement. Pediatrics 2007;120:e215-9.

29. Yu HH, Markowitz R, De Ferranti SD, Neufeld EJ, Farrow $\mathrm{G}$, Bernstein HH, et al. Direct measurement of LDL-C in children: performance of two surfactant-based methods in a general pediatric population. Clin Biochem 2000;33:8995.

30. Srinivasan SR, Frontini MG, Xu J, Berenson GS. Utility of childhood non-high-density lipoprotein cholesterol levels in predicting adult dyslipidemia and other cardiovascular risks: the Bogalusa Heart Study. Pediatrics 2006;118:201-6.

31. Lee KH, Son CS, Lee JW, Tockgo YC. Serum lipids in children and adolescents with family history of coronary artery diseases. J Korean Pediatr Soc 1995;38:482-92.

32. Kavey RE, Allada V, Daniels SR, Hayman LL, McCrindle BW, Newburger JW, et al. Cardiovascular risk reduction in high-risk pediatric patients: a scientific statement from the American Heart Association Expert Panel on Population and Prevention Science; the Councils on Cardiovascular Disease in the Young, Epidemiology and Prevention, Nutrition, Physical Activity and Metabolism, High Blood Pressure Research, Cardiovascular Nursing, and the Kidney in Heart Disease; and the Interdisciplinary Working Group on Quality of Care and Outcomes Research. J Cardiovasc Nurs 2007;22:218-53.

33. Korea Education Development Institute. School health medical examination guideline [Internet]. Seoul: Ministry of Education, Science, and Technology; 2008 [cited 2012 Feb 6]. Available from: http://www.keric.net/keric/search/ SearchControler.jsp? menuchk=yes \&mode $=1 \&$ menuon $=2$ 2\&sortItem=item_pubyear\&pg=6.

34. Rainwater DL, McMahan CA, Malcom GT, Scheer WD, Roheim PS, McGill HC Jr, et al. Lipid and apolipoprotein predictors of atherosclerosis in youth: apolipoprotein concentrations do not materially improve prediction of arterial lesions in PDAY subjects. The PDAY Research Group. Arterioscler Thromb Vasc Biol 1999;19:753-61.

35. Manlhiot C, Larsson P, Gurofsky RC, Smith RW, Fillingham C, Clarizia NA, et al. Spectrum and management of hypertriglyceridemia among children in clinical practice. Pediatrics 2009; 123:458-65.

36. Gidding SS, Dennison BA, Birch LL, Daniels SR, Gillman MW, Lichtenstein AH, et al. Dietary recommendations for children and adolescents: a guide for practitioners: consensus statement from the American Heart Association. Circulation 2005;112:2061-75.
37. Tammi A, Ronnemaa T, Miettinen TA, Gylling H, RaskNissila L, Viikari J, et al. Effects of gender, apolipoprotein E phenotype and cholesterol-lowering by plant stanol esters in children: the STRIP study. Special Turku Coronary Risk Factor Intervention Project. Acta Paediatr 2002;91:1155-62.

38. Laurin D, Jacques H, Moorjani S, Steinke FH, Gagne C, Brun D, et al. Effects of a soy-protein beverage on plasma lipoproteins in children with familial hypercholesterolemia. Am J Clin Nutr 1991;54:98-103.

39. Engler MM, Engler MB, Malloy MJ, Paul SM, Kulkarni KR, Mietus-Snyder ML. Effect of docosahexaenoic acid on lipoprotein subclasses in hyperlipidemic children (the EARLY study). Am J Cardiol 2005;95:869-71.

40. Hong HR, Kim SU, Kang HS. Physical activity and metabolic syndrome in Korean children. Int J Sports Med 2009;30:677-83.

41. Shin KO, Oh SY, Park HS. Empirically derived major dietary patterns and their associations with overweight in Korean preschool children. Br J Nutr 2007;98:416-21.

42. McCrindle BW; American Heart Association Writing Group, Urbina EM, Dennison BA, Jacobson MS, Steinberger J, et al. Summary of the American Heart Association's scientific statement on drug therapy of high-risk lipid abnormalities in children and adolescents. Arterioscler Thromb Vasc Biol 2007;27:982-5.

43. Wiegman A, Hutten BA, de Groot E, Rodenburg J, Bakker HD, Buller HR, et al. Efficacy and safety of statin therapy in children with familial hypercholesterolemia: a randomized controlled trial. JAMA 2004;292:331-7.

44. McCrindle BW, Ose L, Marais AD. Efficacy and safety of atorvastatin in children and adolescents with familial hypercholesterolemia or severe hyperlipidemia: a multicenter, randomized, placebo-controlled trial. J Pediatr 2003;143:74-80.

45. de Jongh S, Ose L, Szamosi T, Gagne C, Lambert M, Scott $\mathrm{R}$, et al. Efficacy and safety of statin therapy in children with familial hypercholesterolemia: a randomized, doubleblind, placebo-controlled trial with simvastatin. Circulation 2002;106:2231-7.

46. Tonstad S, Knudtzon J, Sivertsen M, Refsum H, Ose L. Efficacy and safety of cholestyramine therapy in peripubertal and prepubertal children with familial hypercholesterolemia. J Pediatr 1996;129:42-9.

47. Blagden MD, Chipperfield R. Efficacy and safety of ezetimibe co-administered with atorvastatin in untreated patients with primary hypercholesterolaemia and coronary heart disease. Curr Med Res Opin 2007;23:767-75. 